\title{
The social work regulation project in Aotearoa New Zealand
}

\author{
Sonya Hunt University of Waikato, Aotearoa New Zealand
}

\begin{abstract}
INTRODUCTION: In this second of two articles on the history of professionalisation of social work in Aotearoa New Zealand, consideration is given to the more recent coalescing of forces from the 1990s to the initial implementation of the Social Workers Registration Act (2003), which led to our country's example of a social work regulation project.

APPROACH: This critical consideration of social work regulation in Aotearoa New Zealand situates it within the international social work professionalisation context alongside the national context. Consideration is given to the place of leadership and buy-in from the profession, political sponsorship, cultural considerations, and another ministerial review. Overlaying this, an examination of concepts of public trust, respect, and confidence in professions such as social work, are linked to crises of trust in professions in general, and placed within the current neoliberal, market-driven environment in which this project is anchored.
\end{abstract}

CONCLUSION: The literature serves to document the history of social work regulation in Aotearoa New Zealand and as background for an ongoing research project which aims to uncover interests at work and interrogate the legitimacy of those interests, while enabling the voices of key actors from the time to surface, be explored, and be recorded.

KEYWORDS: social work regulation, regulation project, social worker registration, professionalisation project, social justice

The passing of the Social Workers

Registration Act (SWRA) (2003) represented the culmination of many decades of collective effort to build and strengthen an ethical social work profession in Aotearoa New Zealand (Hancock, 2004), after much debate, ambivalence (Nash \& Miller, 2013), bitterness (Beddoe \& Randal, 1994), tension (van Heugten, 2011) and eventual pragmatic compromise amongst stakeholders

(Corrigan, 2005). Registration became legislated despite the debate at the time over the two distinct and potentially conflicting projects of social work professionalisation and the social justice project (O'Brien, 2005, 2013; Olson, 2007; Orme \& Rennie, 2006). While neoliberal drivers reduce available resources and fragment social work roles contributing to a crisis of trust in the professions, social workers in Aotearoa New Zealand, and internationally remain engaged in the ongoing debate concerning the impact of regulation of the profession (including statutory regulation), particularly in relation to congruence with social work's values of human rights and social justice (Craig, 2002; O'Brien, 2005, 2013; Olson, 2007; Solas, 2008). The potential for professionalisation to enhance practitioner civic literacy and serve the social justice project remains at the core of the social work profession's push for the professionalisation project (Harington, 2006; Harington \& Beddoe, 2013; Olson, 2007).

A coalescing of forces, both international and national, led to the progression of the social
AOTEAROA

NEW ZEALAND SOCIAL WORK 29(1), 53-64.

CORRESPONDENCE TO: Sonya Hunt sonyah@waikato.ac.nz 
work statutory regulation project, a component of the professionalisation project, and the development and initial implementation of the Social Workers Registration Act (2003) in Aotearoa New Zealand.

\section{International social work professionalisation}

The professionalisation project of social work is well under way internationally. The International Association of Schools of Social Work (IASSW) reports that social work is taught at a post-secondary degree level in 125 countries (IASSW, 2012). The International Federation of Social Work (IFSW) and the IASSW focus attention on both the ongoing development of international definitions of social work since the first formal definition was developed in 1957, as well as global standards for social work education (Hare, 2004; IASSW, 2004, 2014; Sewpaul \& Jones, 2005). The definitions and standards reflect the facts that social work is practised in many countries and people are moving between countries, resulting in greater interdependence and the growing impact of international affairs in local situations (Dominelli, 1997, 2010; Dominelli \& Hackett, 2012; Fraser \& Simpson, 2014; Healy \& Meagher, 2004; Ife, 2001; Lyons, 2006). In response to challenges, both internal to the profession (modernist to post-colonial and postmodernist perspectives), and external to the profession (globalisation and neoliberalism), the international social work community has responded with a further, new global definition of social work and a global agenda for social work and social development (Fraser \& Simpson, 2014). Regional and national amplifications of the definition are encouraged, underscoring respect for distinctive regional features and diversity (Staniforth, Fouché, \& O'Brien, 2011). It is argued, therefore, that social workers must connect themselves with their international social work colleagues and recognise the economic, ecological and social forces of globalisation taking into account cultural, political and demographic factors while, at the same time, understand their regional and national environments (Hare, 2004).

A study undertaken by Weiss-Gal and Welbourne (2008) comparing professional features of social work in 10 countries drawn from the five IFSW regions found that, while nearly all these countries had developed professional organisations, a professional code of ethics, the development and dissemination of a specific body of knowledge, and the placement of social work education in tertiary institutions, there was uneven development in other aspects of professionalisation. These aspects included the use of the title social worker, state sanctions for ethical breaches, control over education, training and entry into the profession. This was explained using the power approach (Barretta-Herman, 1993; Freidson, 2001), and differentiated between inner power (social workers as a professional group) and outer or external power (ability of the profession to exert influence outside the profession itself). The authors of the study argued that most of the professional features achieved by social work in the countries studied appear to have been achieved primarily through the profession's inner power and, where external power was required to achieve a professional feature, the results were more uneven (Weiss-Gal \& Welbourne, 2008).

\section{The statutory regulation project in Aotearoa New Zealand}

Leadership from the social work profession, political sponsorship, attention to Treaty obligations and cultural considerations, gradual buy-in from the full membership of the professional association Aotearoa New Zealand Association of Social Workers (ANZASW), led to the involvement of the state in the social work regulation project in Aotearoa New Zealand and the development and implementation of the Social Workers Registration Act (2003). Alongside these developments, ministerial social work practice reviews following deaths of children provided influential political sponsorship and organisational drivers. 


\section{Leadership from the professional body}

By the 1990s, ANZASW had established competency-based membership, and its constitutional arrangements reflected a commitment to biculturalism; as did the addition of Aotearoa to the name of the Association (Hunt, 2016). ANZASW was more representative of social workers in relation to age, employing agency, positions, and qualifications than it had been previously and there was greater internal cohesion within the Association (Randal, 1997). Access to a wide range of training and education courses at all levels of study was also more readily available (Nash, 1998). The Association decided to focus on the issue of registration and, this time, considered models of regulation (Blagdon, Taylor, \& Keall, 1994). The Association preferred social work registration to be based on competency not qualification, something that had not been implemented by any other profession. The groundswell grew for regulation of some description and Keall (1993), National Manager New Zealand Children and Young Persons Service (NZCYPS), stated "the professional challenge for 1993 is for social work and social services organisations and agencies to bite the bullet on social work professionalism and qualifications, includ[ing] the issue of registration...." (p. 5). By 1996, NZCYPS had documented a strategic goal to have an independent registering body for social workers in New Zealand (NZCYPS, 1996).

In the mid-1990s, the president of NZASW stated that the current policy of NZASW was to proceed towards competencybased registration for all social workers in New Zealand and the Association should "actively seek a political sponsor and lobby members of parliament at the earliest practicable opportunity" (Curson, n.d.). This was supported a few years later by the new president of the Association (McNabb, 1997). Social workers in multidisciplinary settings, particularly in the health sector, were also actively seeking professional recognition
(Hunt \& King, 2000; Schofield, 2001) and in July 1997 two ANZASW members drafted a submission to the Committee on the Reform of Health Sector Occupational Regulation Statutes seeking social worker registration (Briggs \& Cromie 1997, cited in McNabb, 1997).

\section{Political sponsorship}

In the mid-1990s, the shadow Minister for Social Welfare agreed to support social worker registration, arguing that trends in social policy had undermined professionalism and it was time to advance the registration of social workers to gain the confidence of the public and fellow professionals, and to obtain greater control over the area of knowledge that defined social work along with clearly defined ethics, competence and accountability (Maharey, 1998). With the 1999 election of a Labour government, social worker registration became part of the government's manifesto, ensuring political support for the project.

\section{ANZASW membership buy-in}

In 1999, members of the Association also voted in support of progressing statutory social worker regulation (Nash \& Miller, 2013). ANZASW formed a registration project team to develop a position on how to achieve registration and the potential policy associated with it (Corrigan, 2000, 2005; Corrigan et al., 2000). Although reservations about registration were expressed, it was argued that, regardless of registration outcome, a strong professional association underpinned by strengthening the partnership and relationships with tangata whenua (Māori indigenous people of the land) was still required for professional accountability and development (Corrigan et al., 2000; Randal, 1999). Overall support for statutory regulation in the form of registration was established to provide a formal mechanism for accountability that ensured consistent minimum ethical standards of practice were met, along with minimum levels of competence, on-going 
professional education, the meeting of obligations under Te Tiriti, and transparent public accountability against a code of conduct regardless of where social workers were employed. Identified reservations included issues of cost, loss of input from the profession to the form statutory regulation would take, the possibility that the legislation could emphasise qualification to the detriment of competence, and the splitting of social worker practitioners into registered and non-registered groups (Corrigan, 2000). These issues remain concerns today (Social Workers Registration Board (SWRB), 2013).

Following the Project Team report (Corrigan et al., 2000), ANZASW produced a policy paper on the statutory registration of social workers, noting that the Māori caucus of the Association, Tangata Whenua Takawaenga o Aotearoa, supported the policy (ANZASW, 2000). Others wrote on the impact of statutory regulation, in its various proposed guises, on social work education (Beddoe, 2000) and health social work (Briggs \& Cromie, 2001), warning of pitfalls and recommending specific foci including becoming a degree-based profession and moving towards mandatory registration.

\section{Ministerial review}

Around the same time, a Ministerial Review of the Department of Child Youth and Family Services (CYFS) resulted in the report "Care and Protection is about Adult Behaviour" (Brown, 2000). This report identified that two major problems with CYFS were inadequacy of resourcing and the lack of adequately trained and professionally supported social workers. Brown recommended that registration of the workforce be given urgency.

\section{The process of developing the regulation}

In July 2000, the Ministry of Social Policy (MSP) released a discussion paper on the registration of social workers. Minister
Maharey stated that he was committed to establishing a social worker registration system as vulnerable and stressed children, young people, families and communities facing difficult issues needed to be able to access high quality and effective services. He further argued that, both the government and public, needed to be able to feel confident in the competence of social workers in whatever sector they were employed. The respondents to the discussion paper were overwhelmingly supportive of some sort of registration for social workers as it was anticipated that this would result in increased safety and protection for all stakeholders (including clients and social workers). Further, it was anticipated that registration would provide avenues to set and maintain high standards of professionalism and minimum standards of required practice as well as provide a formal mechanism for accountability for social work practice (MSP, 2001). The Social Workers Registration Bill was introduced (Social Workers Registration Bill, 2002) and was debated in parliament. During the second reading, the Hon Steve Maharey addressed the issue of mandatory registration, stating that it was not viable to introduce mandatory registration immediately, and also that other forms of occupational regulation were most commonly voluntary. The Bill was read for the third time and a vote resulted in 100 ayes and 6 noes recorded (New Zealand Parliament, 2003).

\section{Treaty obligations}

Simmons-Hansen's (2010) research into the exclusion of submitters' concerns around naming Te Tiriti o Waitangi in the Social Workers Registration Act (SWRA) (2003) argued that the submitters' voices were silenced with the subsequent risk of loss of the bicultural commitment, "just" power relationships and social justice traditions that had been hard won within the profession. However, the resulting SWRA (2003) included some new sections not in the Social Workers Registration Bill which required registered social workers to be competent 
to practise social work with Māori and with different ethnic and cultural groups in New Zealand (SWRA, 2003, s6(c)(i)\&(ii)). Further legislated obligation under s100(i) of the SWRA (2003) required the SWRB to ensure that the aims and aspirations of Māori as tangata whenua were integral and prioritised. Recognition of social work programmes taught at universities, wānanga (Māori universities), polytechnics and private training establishments aims to ensure that graduate outcomes from these degrees include ability to work in a bicultural context and acknowledge the centrality of Te Tiriti o Waitangi to social work practice in New Zealand (Duke, 2012). As this competency is usually missing for overseas qualified social workers moving to New Zealand to work (Bartley et al., 2011; Beddoe, Fouché, Bartley, \& Harington, 2011), the SWRA (2003) s7(f) enables provisional registration while overseas qualified social workers familiarise themselves with the New Zealand bicultural context, usually through short courses of study, and are then able to meet the requirements for full registration.

However, tensions around Treaty obligations remained and following the first review of the SWRA (2003) O'Donoghue (2007) encouraged social workers to re-imagine a system of statutory regulation which "recognise[s] and honour[s] Te Tiriti O Waitangi to the extent that Te Tiriti informs the governance structure and regulatory processes [and forms a] civic partnership between state, profession and iwi [and] also supports the self-determination of iwi in relation to Māori interests and Māori social work practice" (p. 1).

\section{The implementation of the SWRA (2003)}

The purpose of the SWRA (2003) as outlined in $\mathrm{s} 3$ is four-fold and includes protecting the members of the public by prescribing or providing mechanisms to ensure that social workers are competent to practice and accountable for the way in which they practise. It created a framework for the registration of social workers in

New Zealand by establishing both a board to register social workers and a tribunal to hear complaints about registered social workers; providing for the SWRB to promote the benefits of registration of social workers; and finally, enhancing the professionalism of social workers.

The MSP called for nominations and expressions of interest for appointment to the inaugural SWRB. In October 2003, nine people were appointed by the Minister of Social Welfare to form the inaugural SWRB: Robyn Corrigan, Buster Curson, John Dunlop, Shannon Pakura, Liz Beddoe, Yvonne Crichton-Hill, Jan Duke, Ian Calder and Sonya Hunt. These people represented past and present office holders of ANZASW, senior academics and managers of nongovernmental organisations (NGOs), practising and non-practising social workers, men, women, Māori, Pasifika and other groupings. However, the SWRB members were all appointed as individuals, not representatives of any particular body or group. Regardless, the Minister clearly indicated that this Board was a professional instrument as all nine initial members were eligible for registration (Beddoe \& Duke, 2009). The Act provides for 10 members on the SWRB, and the final member, Paul Curry, was appointed the following year.

At the launch of the SWRB and the SWRA (2003) on November 5, 2003, the President of IFSW stated that "the demonstration of contemporary knowledge, skills, experience and competence to practice can only be effectively supported through a framework that includes registration of social workers" (Dodds, 2004, p. 2), noting that, while the Act provided for voluntary social worker registration, this was not the preferred position of ANZASW or of the IFSW. Merv Hancock, the inaugural president of NZASW and a life member of the Association, also spoke at the launch and reflected that building an ethical social work profession takes time, organisation, advocacy, debate, staying together amid division, meeting the 
challenge of the Treaty, holding on when membership falls, new approaches, and new advocacy for statutory registration. He focused on three themes to conclude his speech: "the ethical core of the social work profession, the independence of the social work profession, and the advocacy role of the Association" (Hancock, 2004, p. 1).

A month later, the SWRB held its first meeting to consider the functions of the Board listed under s99 of the SWRA (2003). The legislation stipulated that, to be entitled to be a New Zealand registered social worker, a person was required to have a recognised Aotearoa New Zealand qualification and satisfy the Board that they were both competent and fit and proper to practise social work. In addition they were required to be competent to practise with Māori and with different ethnic and cultural groups within Aotearoa New Zealand. Finally they also had to have enough practical experience in practising social work (SWRA 2003, s6). Overseas qualified social workers also had a pathway for registration outlined in s7. Applicants who had neither a recognised Aotearoa New Zealand qualification nor an equivalent overseas qualification, were also eligible for registration under s13 if the SWRB was satisfied the applicant's practical experience in practising social work in Aotearoa New Zealand was enough to compensate for the lack of such a qualification.

Establishment funding from the Ministry of Social Development was provided in the first three years (SWRB, 2004a, 2005, 2006), but after this period the Board was required to be financially independent and therefore required sufficient applications, registration fees and discipline levies to be financially sustainable. The inaugural SWRB consulted with key stakeholders and by May 2004 had met with ANZASW, CYFS, Te Kaiāwhina Ahumahi (The New Zealand Council of Education and Training), the Council of Christian Social Services, the New Zealand Federation of Voluntary Welfare Organisations, and Aotearoa
New Zealand Association of Social Work Educators (Corrigan, 2005). Position papers were being developed then by the SWRB for determining competence, fit and proper status, Aotearoa New Zealand recognised qualifications in social work, and what constituted enough practical experience. These papers were then circulated for comment and feedback (SWRB, 2004a, 2004b, 2004c, 2004d).

Much was achieved in that first year but the costs of the process were high for the individuals involved. Relationships with key stakeholders including practitioners, educators, employers, professional bodies and users changed (Corrigan, 2005). Many social work practitioners had to complete social work qualifications and undergo a competency assessment to obtain social worker registration (Beddoe, 2007; Beddoe \& Duke, 2009). ANZASW, in particular, was challenged with the changing focus of experienced people who had previously contributed fully to the Association's operations to SWRB business, and also by the disconnect between the role of ANZASW (which was to promote the interests of its members) and SWRB which was required to promote public accountability in the profession (Corrigan, 2005; Henderson \& O'Donoghue, 2013). All parties involved had to develop an understanding of the nature and parameters of statutory regulation (Beddoe \& Duke, 2009).

Stakeholder buy-in from CYFS seemed assured. They released the "Child Youth and Family Social Work workforce and capability Plan" (2004) which identified the three goals of retention, professionalism, and recruitment with the aim of developing a fully qualified and registered workforce (Tyler, 2004). In the SWRB (2015) 2014-2015 Annual Report, it was noted that CYFS was the single largest employer of registered social workers (1377 registered social workers indicating this), demonstrating a huge commitment by the department, the largest single employer of social workers. The health sector social worker workforce also featured highly in the 
registered social worker statistics with over 1273 District Health Board social workers registered (SWRB, 2015) and the majority of District Health Boards had social worker registration policies in place (Gilray, 2013). However, social workers in this sector did not have initial unanimous support to be registered by their employing District Health Board and this had to be addressed by the SWRB and the sector and included ministry engagement. The second review of the SWRA (2003) completed in 2012 found that government agencies had a greater uptake of social worker registration than NGOs (SWRB, 2012b). Some NGOs expressed a desire to employ registered social workers, and included upskilling staff utilising the NGO Study Award offered by the Ministry of Social Development as a requirement in new recruits' employment contracts (Smith, 2013).

\section{The political landscape for professions}

As noted in Hunt (2016), the journey to professionalisation of any occupational group is one beset by barriers and challenges within the social milieu, and given the political sensitivity attached to much social work activity, it is unsurprising that the social work professional project received government attention. This final section of the paper considers the impact of the neoliberal, market-driven political environment in which the Aotearoa New Zealand social work regulation project is anchored. The added complexity of the crisis of trust in professions noted by Evetts (2006) and others is also explored.

\section{The crisis of trust with professions}

The linking of trust and professionalism remains a popular discourse despite challenges to the image of social work professionals through the publication of the outcomes of the SWRB Complaints and Disciplinary Tribunal (SWRB, 2016) as well as media coverage of high-profile scandalous proven (or unproven) cases of negligence or malpractice (Radio New Zealand, 2015).
There is evidence that media influences the public perception of social workers with a focus on bad practice being seen as more newsworthy (Brown, 2000; Staniforth, Fouche, \& Beddoe, 2014). Political negativity and scapegoating of the profession has also influenced the public perception of the profession with recent statements made by politicians and others in high-profile roles attacking the capability of social workers and tertiary programmes of social work education (Bennett transcribed speech, November 11, 2013, in Beddoe, 2014; Ryan, 2015, April 2). Other professions, such as the medical and legal professions, provide high-profile scandals such as the medical Dr Harold Shipman case which resulted in a criminal conviction of mass murder for killing more than 200 of his patients (Biography.com Editors, n.d.). This has resulted in intense public scrutiny of the concept of trust of professions (Evetts, 2006). Staniforth et al. (2014) found that, while there was a level of public confidence in social workers, there is much to do in terms of role clarification for the profession and there is "no room for complacence" (p. 59).

Maharey (2003), in his keynote speech to the 21 years SW@ACE Conference, a few months after the passing of the SWRA (2003), utilised a traits approach (Flexner, 2001/ 1915 Hunt, 2016) to explain professionalisation when listing seven characteristics commonly associated with defining a profession and arguing that social work in New Zealand met these characteristics. However, he also stated that, "ultimately one of the keys of professionalisation is recognition by the community [and] this is about gaining respect and trust." He argued that the community needed to be convinced that social work practice was high quality, effective and in clients' best interests. He identified current issues facing social work: less than 20 percent of social workers hold a bachelor-level qualification or above; a declining supply of highly skilled and knowledgeable practitioners; increased complexity in the work social workers must address; and low remuneration for 
social work caused, in part, by the female domination of the role. He argued that the government believed that the key to enhancing the professionalism of social work was registration of social workers.

\section{Neoliberal, market-driven political environment}

Consideration of the regulation project within a neoliberal, market-driven environment is also necessary. It is recognised that social work in the context of an economic marketplace which accepts reduced resources particularly for preventative work, fragmentation of roles, evidence-based practice requirements and a competencies approach also reduces the opportunity and capability of the profession to respond to issues of social justice including Treaty obligations (Dominelli, 1996; Ferguson \& Lavalette, 2006; Garrett, 2009; Healy \& Meagher, 2004; Hugman, 1996; van Heugten, 2011; Wallace \& Pease, 2011). It is argued that social welfare professions have been undermined by the "corrosive effects of New Public Management" (Healy, 2009, p. 401) and that many of the key elements confronting professionalism such as audit, performance management, and managerialism involve conflict as opposed to consensus and trust, and actually require professionalism to connect with "more democratic forms of accountability and governance" (Gleeson \& Knights, 2006, p. 290). New patterns of building trust are required in order for users and providers to have "rational criteria" and "visible markers" of quality service (Kuhlmann, 2006), while professional work, action and trustworthiness require new analytical, social and moral foundations (Olgiati, 2006). Noordegraaf (2007) suggests reinterpreting professionalism so that it is not solely about occupational control (pure professionalism), or organisational control (situated professionalism), to include both sociocultural make-up (knowledge workers, organisational professionals) and also workrelated respects (inferential, experiential). Professionalism would thus be viewed as reflexive control or a professional use of professionalism. Noordegraaf (2007) argues this is "highly relevant in ambiguous domains in which expertise can no longer be isolated from other experts, decision makers or clients" (p. 780). Further:

$[\mathrm{P}]$ rofessionalism is used not so much to improve organizational contexts but to improve the idea of professionalism in changing organizational contexts. Hybridized professionalism offers new opportunities for maintaining the notion of professionalism in times that weaken the notion of professionalism. (Noordegraaf, 2007 p. 775)

\section{Conclusion}

The SWRA (2003) aligned social work in New Zealand with other professions (those covered by the Health Professionals Competency Assurance Act 2003, law, teaching and many others) and also with social work in other countries including Canada, England, France, Northern Ireland, Scotland, South Africa, the United States, Hong Kong, Romania and others. While the main aim of social worker statutory regulation was to protect the public and ensure minimum standards of practice (Gilray, 2013), it also enhanced social work's claim to the professional domain. The SWRA (2003) reflected a pragmatic compromise by many of the key actors at the time including the national professional body, the ANZASW tangata whenua caucus, the state, educators and trainers, employers and social workers themselves. The enabling legislation required consultation and debate with the stakeholders and, ultimately the decision-making was bound to disappoint all the stakeholders to some degree. The full purpose of the SWRA (2003) could arguably be only partially achieved with the voluntary system of regulation. While the state responded to the riskiness of social work and a number of child abuse tragedies by initiating limited social worker registration, the lack of protection of title in the SWRA (2003) means anyone is entitled 
to claim the title of social worker and it is up to employers to determine if they require registered social workers. The political commitment to mandate occupational closure for social work is not yet evidenced, despite almost unanimous critique of the current voluntary system (SWRB, 2007, 2011, 2012a). An inquiry into the operation of the SWRA (2003) is currently being conducted by a Parliamentary Select Committee (New Zealand Parliament, 2016).

Concerns remain however, that the instigation of mandatory registration might not improve ethical practice, education and standards. Regulation of social work remains a contestable construct. Rather, it is feared that universal regulation of social workers might bring greater government and political control, weaken academic independence and divert the profession's focus on social justice and addressing poverty (Harington, 2006; Kean, 2007; O'Brien, 2005; Orme \& Rennie, 2006; Rennie, 2013; van Heugten, 2011). The neoliberal political environment serves to further compound the weakening of the social justice, community development and strength building roles of the social work profession. The profession's challenge is to ensure that the social work regulation project in Aotearoa New Zealand supports the opportunity for the ongoing development of practitioner scholarship, civic literacy and responsibility to utilise theory, provide ethical care, respond to political forces that exacerbate injustice and retain the dream of social justice within both the social work professionalisation and regulation projects.

\section{References}

Aotearoa New Zealand Association of Social Workers (2000). Policy paper on the statutory registration of social workers. Dunedin, NZ: Author.

Barretta-Herman, A. (1993). Development of social work in New Zealand: 1969-1988. Part II: Social work professionalism. Social Work Review, 5(5), 30-35.

Bartley, A., Beddoe, L., Duke, J., Fouche, C., Harington, P., \& Shah, R. (2011). Crossing borders: Key features of migrant social workers in New Zealand. Aotearoa New Zealand Social Work, 23(3), 16-30.

Beddoe, L. (2000). Registration ... coming ready or not: The impact on social work education. Social Work Review, 12(3), 2-5.
Beddoe, L. (2007). Change, complexity and challenge in social work education in Aotearoa New Zealand. Australian Social Work, 60(1), 46-55. doi:10.1080/03124070601166703

Beddoe, L. (2014). A matter of degrees: The role of education in the professionalisation journey of social work in New Zealand. Aotearoa New Zealand Social Work, 26(2\&3), 17-28.

Beddoe, L., \& Duke, J. (2009). Registration in New Zealand social work: The challenge of change. International Social Work, 52(6), 785-797. doi:10.1177/0020872809342649

Beddoe, L., Fouché, C., Bartley, A., \& Harington, P. (2011). Migrant social workers' experience in New Zealand: Education and supervision issues. Social Work Education, 31(8), 1012-1031. doi:10.1080/02615479.2011.633600

Beddoe, L., \& Randal, H. (1994). The New Zealand Association of Social Workers: The professional response to a decade of change. In R. Munford \& M. Nash (Eds.), Social work in action (pp. 21-36). Palmerston North, NZ: The Dunmore Press.

Biography.com Editors (n.d.). Harold Shipman biography. Retrieved from http://www.biography.com/people/ harold-shipman-17169712

Blagdon, J., Taylor, M., \& Keall, B. (1994). Social worker registration. Social Work Review(June), 24-25.

Briggs, L., \& Cromie, B. (2001). Editorial, registration issues for health social work: Will social workers become second tier health professionals? Social Work Review, 13(2), 1

Brown, M. (2000). Care and protection is about adult behaviour: The ministerial review of the Department of Child, Youth and Family Services. Wellington, NZ: Department of Child Youth and Family Services.

Corrigan, R. (2000). Position paper on the statutory registration of social workers, August 2000. Social Work Review, 12(2), 3-7.

Corrigan, R. (2005). A futuristic challenge. Te Komako: Social Work Review, 17(Winter), 20-25.

Corrigan, R., Semmons, W., Clark, K., Taylor, M., McPherson, C., Cromie, B., ... Randal, H. (2000). Statutory registration for social workers. Social Work Review, 12(1), 18-23.

Craig, G. (2002). Poverty, social work and social justice. British Journal of Social Work, 32(6), 669-682. doi:10.1093/bjsw/32.6.669

Curson, B. (n.d.). NZASW: Registration of social workers. Position paper.:Wellington, NZ: NZASW.

Dodds, I. (2004). A contemporary framework for the accountability of social workers' practice. Aotearoa New Zealand Social Work, 16(1), 2-5.

Dominelli, L. (1996). Deprofessionalizing social work: Antioppressive practice, competencies and postmodernism. British Journal of Social Work, 26(2), 153-175.

Dominelli, L. (1997). Keynote address: Educating social workers in a changing cultural context: Social work under globalisation. Social Work Review, 9(4), 3-8.

Dominelli, L. (2010). Globalization, contemporary challenges and social work practice. International Social Work 53(5), 599-612. doi:10.1177/0020872810371201 
Dominelli, L., \& Hackett, S. (2012). Social work responses to the challenges for practice in the 21st century. International Social Work, 55(4), 449-453. doi:10.1177/0020872812440784

Duke, J. (2012). Registration and professional practice Social Work Now, 51, 9-16.

Evetts, J. (2006). Introduction: Trust and professionalism: Challenges and occupational changes. Current Sociology, 54(4), 515-531. doi:10.1177/0011392106065083

Ferguson, I., \& Lavalette, M. (2006). Globalization and global justice: Towards a social work of resistance. International Social Work, 49(3), 309-318. doi:10.1177/0020872806063401

Flexner, A. (2001/1915). Is social work a profession? Research on Social Work Practice, 11(2), 152-165. doi:10.1177/104973150101100202

Fraser, S., \& Simpson, S. (2014). Always take the weather with you: Aotearoa New Zealand social work in a dynamic global society. Aotearoa New Zealand Social Work, 26(2\&3), 29-38.

Freidson, E. (2001). Professionalism: The third logic Chicago, IL: University of Chicago Press.

Garrett, P. M. (2009). Examining the "conservative revolution": Neoliberalism and social work education. Social Work Education, 29(4), 340-355. doi:10.1080/02615470903009015

Gilray, B. (2013). Social worker registration: A decade of development, debate, delivery. Aotearoa New Zealand Social Work, 25(3), 25-34

Gleeson, D., \& Knights, D. (2006). Challenging dualism: Public professionalism in "troubled" times. Sociology, 40(2), 277-295. doi:10.1177/0038038506062033

Hancock, M. (2004). Building an ethical social work profession. Social Work Review, 16(Autumn), 1.

Hare, I. (2004). Defining social work for the 21st century: The International Federation of Social Workers' revised definition of social work. International Social Work, 47(3), 407-424. doi:10.1177/0020872804043973

Harington, P. (2006). Practitioner scholarship and civic literacy: Will registration lift the game? Social Work Review, 18(Summer), 90-99.

Harington, P., \& Beddoe, L. (2013). Civic practice: A new professional paradigm for social work. Journal of Social Work, 4(2), 47-64. doi:10.1177/1468017313477316

Healy, K. (2009). A case of mistaken identity: The social welfare professions and new public management. Journal of Sociology, 45(4), 401-418. doi:10.1177/1440783309346476

Healy, K., \& Meagher, G. (2004). The reprofessionalization of social work: Collaborative approaches for achieving professional recognition. British Journal of Social Work 34(2), 243-260. doi:10.1093/bjsw/bch024

Henderson, R., \& O'Donoghue, K. (2013). A former president reflects on the effects of social worker registration upon the association: An interview with Rose Henderson. Aotearoa New Zealand Social Work, 25(3), 60-67.

Hugman, R. (1996). Professionalization in social work: The challenge of diversity. International Social Work, 39(2), 131-147. doi:10.1177/002087289603900203
Hunt, S. (2016). The social work professionalisation project before the 1990s in Aotearoa New Zealand: The dream Aotearoa New Zealand Social Work, 28(3), 15-25. doi:10.11157/anzswj-vol28iss3id245

Hunt, S., \& King, T. (2000). Allied health: Aligned for empowerment. Social Work Review. 12(3), 13-19.

IASSW. (2004). The global qualifying standards for social work education and training. Retrieved from http://www.iassw-aiets.org/

IASSW. (2012). Directory of social work schools/programmes 2011. Retrieved from http://www.iassw-aiets.org/uploads/ file/20121025_IASSW-Directory-October-2012.pdf

IASSW. (2014). Global definition of social work. Retrieved from http://www.iassw-aiets.org/

Ife, J. (2001). Local and global practice: Relocating social work as a human rights profession in the new global order. European Journal of Social Work, 4(1), 5-15. doi: $10.1080 / 714052835$

Keall, B. (1993). Biting the bullet: Professionalism. Social Work Review, 5(3), 4-6.

Kean, J. (2007). Professional ethics versus institutional expectations. Aotearoa New Zealand Social Work Review, 19(2), 37-41.

Kuhlmann, E. (2006). Traces of doubt and sources of trust: Health professions in an uncertain society. Current Sociology, 54(4), 607-620. doi:10.1177/0011392106065092

Lyons, K. (2006). Globalization and social work: International and local implications. British Journal of Social Work, 36(3), 365-380. doi:10.1093/bjsw/bcl007

Maharey, S. (1998). Social policy, social work and professionalism. Social Work Review, 10(4), 25-26.

Maharey, S. (2003, July 17). A social work profession: Challenges to educators. Keynote address to the 21 Years SW@ACE Conference. Auckland College of Education, Centre for Social Work, Auckland, New Zealand.

McNabb, D. (1997). Registration for New Zealand social workers? Social Work Review, 9(4), 43-45.

Ministry of Social Policy. (2001). Registration of social workers: Consultation summary report. Retrieved from https://www.msd.govt.nz/documents/about-msd-and-ourwork/publications-resources/archive/2001-reg_socwork_ consultationsummary.pdf

Nash, M. (1998). People, policies and practice: Social Work education in Aotearoa/New Zealand from 1949-1995. (Doctoral dissertation). Massey University, Palmerston North, New Zealand. Retrieved from http://hdl.handle. net/10179/2014

Nash, M., \& Miller, J. (2013). Social work: Where have we been and where are we going. In M. Connolly \& L. Harms (Eds.), Social work: Contexts and practice (pp. 329-345). Melbourne, VIC: Oxford University Press.

New Zealand Children and Young Persons Service. (1996). Professionalisation strategy. Wellington, NZ: Author.

New Zealand Parliament. (2003). Social Workers Registration Bill - Second reading, in committee, third reading. Wellington, NZ: Hansard and Journals. Retrieved from http://www.parliament.nz/en-nz/pb/ debates/debates/47HansD_20030403_00001124/socialworkers-registration-bill-\%E2\%80\%94-second-readingin-committee. 
New Zealand Parliament. (2016). Inquiry into the operation of the Social Workers Registration Act, 2003. Wellington, NZ. Retrieved from https://www.parliament. nz/en/pb/sc/make-a-submission/document/51SCSS_ SCF_00DBSCH_INQ_69225_1/inquiry-into-theoperation-of-the-social-workers-registration

Noordegraaf, M. (2007). From "pure" to "hybrid" professionalism: Present-day professionalism in ambiguous public domains. Administration \& Society, 39(6), 761-785. doi:10.1177/0095399707304434

O'Brien, M. (2005). A just profession or just a profession? Social work and social justice. Social Work Review, 17(1), 13-22.

O'Brien, M. (2013). Social work registration and professionalism: Social justice and poverty - fellow travellers or discarded passengers? Aotearoa New Zealand Social Work, 25(3), 50-59.

O'Donoghue, K. (2007). Guest editorial: Re-imagining registration. Dream the dream! Social Work Review, 19(3), 1-2.

Olgiati, V. (2006). Shifting heuristics in the sociological approach to professional trustworthiness: The sociology of science. Current Sociology, 54(4), 533-547. doi:10.1177/0011392106065085

Olson, J. J. (2007). Social work's professional and socia justice projects: Discourses in conflict. Journal of Progressive Human Services, 18(1), 45-69. doi:10.1300/ J059v18n01_04

Orme, J., \& Rennie, G. (2006). The role of registration in ensuring ethical practice. International Social Work, 49(3), 333-344. doi:10.1177/0020872806063405

Radio New Zealand (Writer). (2015). Social worker cleared of having sex with her underage client [Radio broadcast]. Retrieved from http://www.radionz.co.nz/national/ programmes/checkpoint/audio/201775977/social-workercleared-of-having-sex-with-her-underage-client

Randal, H. (1997). Competent practice and its regulation: Debating the issues around the registration and professionalisation of social work in New Zealand. Social Work Review, (March-June), 16-19.

Randal, H. (1999). Guest editorial: Accountability for social work. Social Work Review, 12(1), 1-2.

Rennie, G. (2013). Registration ten years on: A perspective from a social work educator. Aotearoa New Zealand Social Work, 25(3), 3-10.

Ryan, K. (Writer). (2015, April 2). What needs to change at Child Youth and Family? [Radio broadcast], Nine to Noon. Retrieved from http://www.radionz.co.nz/national/ programmes/ninetonoon/audio/20173411/what-needsto-change-at-child-youth-and-family

Schofield, V. (2001). Health social work. In M. Connolly (Ed.), New Zealand social work: Contexts and practice (pp. 146-156). Auckland, NZ: Oxford University Press.

Sewpaul, V., \& Jones, D. (2005). Global standards for the education and training of the social work profession. International Journal of Social Welfare, 14, 218-230. doi:10.1111/j.1468-2397.2005.00362.x

Simmons-Hansen, M. (2010). Lost voices:Why is Te Tiriti not named in the Social Work Registration Act (SWRA) 2003? (Master of Social Work (Applied) dissertation). Massey University, Palmerston North, NZ. Retrieved from http://www.scribd.com/doc/178796215/Lost-voice5-AUGUST-pdf-Submissions-and-the-disconnectaround-the-Registration-of-Social-Workers-Act-2003
Smith, P. (2013). Registration: Ten years on within a nongovernment organisation. Aotearoa New Zealand Social Work, 25(3), 19-24.

Social Workers Registration Act 2003, 2003 S.N.Z. No. 17.

Social Workers Registration Bill. (2002). Explanation note general policy statement. Wellington, New Zealand: Parliamentary Library Services, Parliament.

Social Workers Registration Board. (2004a). Annual Report: 2003-2004. Wellington, New Zealand: Author. Retrieved from http://www.swrb.govt.nz/news-and-publications/ publications

Social Workers Registration Board. (2004b). Entitlement to registration: Competence policy statement. Retrieved from http://swrb.org.nz/Documents/Competence.pdf

Social Workers Registration Board. (2004c). Entitlement to registration: Criteria: Fit and proper person: A position paper. Wellington, NZ: Author.

Social Workers Registration Board. (2004d). New Zealand recognised qualifications in social work: A discussion paper. Wellington, NZ: Author.

Social Workers Registration Board. (2005). Annual report: 2004-2005. Wellington, NZ: Author. Retrieved from http://www.swrb.govt.nz/news-and-publications/ publications

Social Workers Registration Board. (2006). Annual report: 2005-2006. Wellington, NZ: Author. Retrieved from http://www.swrb.govt.nz/news-and-publications/ publications

Social Workers Registration Board. (2007). Social Workers Registration Act 2003: Review Report (July). Wellington, NZ: Author. Retrieved from http://www.swrb.govt.nz/ news-and-publications/publications

Social Workers Registration Board. (2011). Mandatory social worker registration: A discussion paper. Wellington, NZ: Author. Retrieved from http://www.swrb.govt.nz/newsand-publications/publications.

Social Workers Registration Board. (2012a). Mandatory social worker registration: Report on the discussion paper of 2011. Wellington, NZ: Author. Retrieved from http://www.swrb.govt.nz/news-and-publications/ publications

Social Workers Registration Board. (2012b). Social Workers Registration Act 2003: Review Report. (October). Wellington, NZ: Author. Retrieved from http://www.swrb. govt.nz/news-and-publications/publications

Social Workers Registration Board. (2013). Annual report: 2012-2013. Wellington, NZ: Author. Retrieved from http://www.swrb.govt.nz/news-and-publications/publications.

Social Workers Registration Board. (2015). Annual Report: 2014-2015. Wellington, NZ: Author. Retrieved from http://www.swrb.govt.nz/news-and-publications/publications

Social Workers Registration Board. (2016). Complaints and Disciplinary Tribunal: Decisions. Retrieved from http:// www.swrb.govt.nz/complaints/tribunals-decisions

Solas, J. (2008). What kind of social justice does social work seek? International Social Work, 51(6), 813-822. doi: $10.1177 / 0020872808095252$

Staniforth, B., Fouche, C., \& Beddoe, L. (2014). Public perceptions of social work and social workers in Aotearoa New Zealand. Aotearoa New Zealand Social Work, 26(2\&3), 48-60. 


\section{ORIGINAL ARTICLE}

\section{THEORETICAL RESEARCH}

Staniforth, B., Fouché, C., \& O'Brien, M. (2011). Still doing what we do: Defining social work in the 21st century. Journal of Social Work, 11(2), 191-208. doi:10.1177/1468017310386697

Tyler, P. (2004). Editorial. Social Work Now, 29, 2.

van Heugten, K. (2011). Registration and social work education: A golden opportunity or a Trojan horse? Journal of Social Work, 11(2 ), 174-190. doi:10.1177/1468017310386695

Wallace, J., \& Pease, B. (2011). Neoliberalism and Australian social work: Accommodation or resistance? Journal of Social Work, 11(2), 132-142. doi:10.1177/1468017310387318

Weiss-Gal, I., \& Welbourne, P. (2008). The professionalisation of social work: A cross-national exploration. International Journal of Social Welfare, 17(4), 281-290. doi:10.1111/j.1468-2397.2008.00574.x 